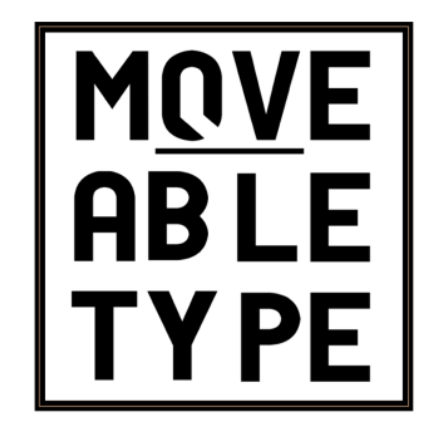

'Decadence, Homoeroticism and the Turn Towards Nature in James Bidgood's Pink Narcissus'

Author[s]: James Jackson

Source: Moveable Type, Vol.11, 'Decadence' (2019)

DOI: $10.14324 / 111.1755-4527.097$

Moveable Type is a Graduate, Peer-Reviewed Journal based in the Department of English at UCL.

(C) 2019 James Jackson. This is an Open Access article distributed under the terms of the Creative Commons Attribution License (CC-BY) 4.0https://creativecommons.org/licenses/by/4.0/, which permits unrestricted use, distribution, and reproduction in any medium, provided the original author and source are credited.

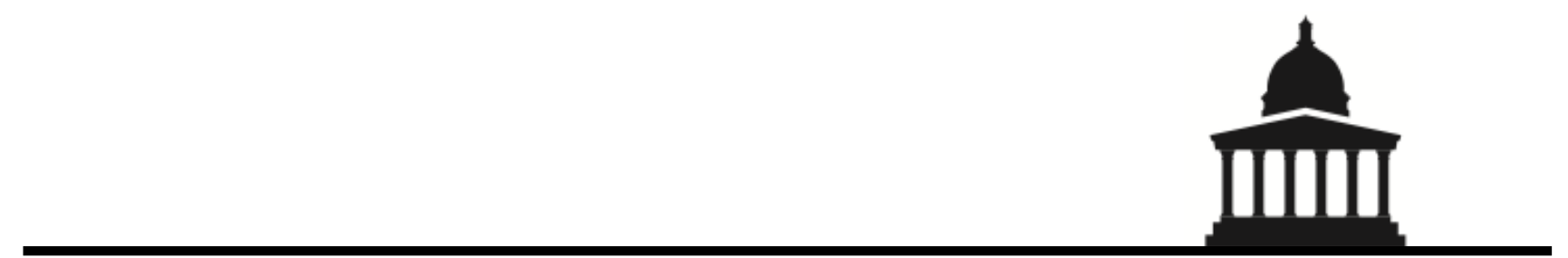




\section{Decadence, Homoeroticism \& the Turn Towards Nature in James Bidgood's Pink Narcissus}

James Jackson

This essay argues that James Bidgood's Pink Narcissus, a 1971 arthouse film produced in the confines of the director's apartment in the years leading up to the Stonewall Rebellion in June 1969 and released almost two years later in New York when homosexuality had been legalised, responds creatively to the moral and legal restrictions placed upon homosexuals during its production. Bidgood's juxtaposition of the camp, rosy world of the narcissist's apartment, where the character contemplatively fantasises about his natural desires and sexual encounters, with the harsh, animalistic world of the city underground, where gay men go searching discreetly for one-off encounters, taking risks along the way, mirrors the world of the New York underground scene inhabited by Bidgood in the 1960s. The pleasant aroma felt as Bidgood whisks Pan away from the brightly coloured and elaborately decorated apartment to fantastical, dreamlike spaces, illuminates the desire of the character to act in ways he cannot in the outside world, and to distance himself from the harsh realities of life's underbelly. By drawing on historical, cultural, and natural imagery in his depictions of Pan's roleplaying fantasies, Bidgood does not merely acknowledge the common assumption — in the time this film was being made — of homosexual acts being socially and morally transgressive, but actively challenges it by giving us a perspective on homosexuality that goes beyond the social and moral and embraces the full beauty of homosexuality in nature. Bidgood though recognises not only the beauty associated with homosexuality but the power of nature in general, hence why he simultaneously reveals to us the fear of the unknown and the potential, animalistic dangers associated with the sexual undervorld he was part of in the 1960s. The aesthetic of benevolence, beauty, and homoeroticism, so often seen in clichéd, camp depictions of homosexuality, is used ironically by Bidgood to remind us that it is merely a veneer for those more dangerous encounters. Bidgood then presents a holistic view of homosexuality, with decadence a characteristic showing what lies beneath the homoerotic surface, projected through the fantasies and risk-taking of the film's main protagonist.

$$
\text { * * * }
$$

James Bidgood's Pink Narcissus (1971) is a masterpiece of American art house cinema and a triumph of low-budget filmmaking, aimed firmly at the homosexual community. In the seven years between 1963 and 1970 it took Bidgood to painstakingly film his chef d'oeuvre, the Stonewall rebellion had taken place and many gay people were migrating to the cities. Bidgood's search for models in an early 1960s New York where homosexuals spent most of their time 'underground' was a precarious one. Who on the city streets could Bidgood safely ask to go back to his apartment to model for a homosexual film?' Bobby Kendall, who plays Pan (alluding to the Greek god of nature and the wilds), was easily approachable, as he shared

\footnotetext{
${ }^{1}$ Sean Edgecomb, "Camping Out With James Bidgood: The Auteur Of Pink Narcissus Tells All - Bright Lights Film Journal", Bright Lights Film Journal, $2019<$ https://brightlightsfilm.com/wpcontent/cache/all/camping-james-bidgood-auteur-pink-narcissus-tells/\#.XFIYufZ2vmI> [Accessed 30 January 2019].
} 
an apartment with Bidgood at the time and continued to do so during the production of the film. His sexuality remains mostly in the dark though, unlike Charles Ludlam (one of his costars), who was openly homosexual. Aside from Kendall, Ludlam, and their other co-star, Don Brooks, finding suitable models to perform in a homoerotic fashion by just heading out onto the streets would have been unpredictable and volatile, just like the underworld we see in the film itself.

Whilst the need for absolute discretion or anonymity somewhat faded by the time Pink Narcissus was finally released in May 1971, Bidgood remained anonymous in the credits due to creative tensions with the editors. The film, which is about the sexual fantasies of a youthful gay prostitute working in the city, alludes to this notion of the homosexual man as an individual who goes forth into the transient city seeking independence and autonomy, in the process transcending the moral constraints of a particular world (such as the Protestantism embedded in so much of American culture in the 1960s), but which began to wane as the decade progressed. Given that the entire film was shot on sets created by Bidgood in his own apartment, and that Bidgood searched the streets for models, the film itself is an allegory on the very process of its making, and a broader commentary on difficulties faced by homosexual people in the underground during the 1960s. However, Bidgood portrays homosexuality not as decadent because it challenges what had up until recently been seen as morally wrong in the legal and social realm per se, but rather as a natural phenomenon, where in the sexual underworld, nature herself unleashes the opposing tenets of benevolent beauty and harsh animalism associated with sexual desire. The film's esoteric and soft-pornographic nature plays to the fantasies of the peripheral, underground audience it was aimed at; the camp, homoerotic aesthetic evoked so potently by Bidgood, and dismissed as outmoded and anachronistic by those who began to find enjoyment in more masculine, hardcore depictions of homosexuality, as in Poole's Boys in the Sand (1971), has a doubly ironic effect. ${ }^{2}$ The film was actually mistaken for one of Warhol's. The colour pink, whose connotations at this time were so often tenderness and femininity — often thought to be have been popularised by the pink dress worn by Mamie Eisenhower at her husband's presidential inauguration in 1953 ('Mamie Pink'), and used as part of a man's costume or in the décor of his living space to playfully imply his homosexuality-is splashed everywhere in the film and seen by some as a

\footnotetext{
2 When I talk of Bidgood's depiction of camp having a 'doubly ironic effect', I am suggesting two things. The first is that, in accordance with a trait of camp outlined by Sontag in her essay, "Notes on "Camp", [Susan Sontag, Against Interpretation and Other Essays (London: Penguin Books, 2009), pp. 275-292], the aesthetic plays on its own artificiality. The second is that Bidgood knowingly acknowledges and pokes fun at this insistence on an artificial depiction of man in the first place.
} 
hangover from the 1960s. ${ }^{3}$ The colours and tones of the film's world knowingly play on the innocence and sweetness to reinforce that this aesthetic is a veneer under which there are various layers of the homosexual underworld, something that discerning homosexual audiences most likely knew to be true.

Symbols and allegories alluding to the historical representation of sexual experience, not just sexuality, all converge in the protagonist, whose obsession with his own desires are reflected back at him in the hall-of-mirrors-esque images we see throughout this film. Ovid's tale of Narcissus is of a man who falls in love with his own reflection. Narcissus is seen only to really love himself, believing nobody else is worthy of his love; the feeling of being momentarily desired or fleetingly loved by others is for him insignificant. An obsession with the self is a significant part of this film, but within this is the underlying cycle of perceived decadence, which goes from innocence to depravity to innocence. But what of the relationship more generally between decadence, sex, and culture? Paglia argues that decadence can be found most prominently in the mythic objet d'art of the Graeco-Roman world, the humanistic paintings and sculptures of the Renaissance, and in the nature-inspired poems of Romanticism. She sees a schism in life between Apollo and Dionysus (the chthonic world); religiosity and paganism; rationality and chaos. ${ }^{4}$ The three markers of decadence she sets out are an eruption of those things which deviate from rigid moral codes of society and religion.

The Hellenistic period in late Rome embraced a decadent culture: it became secularised, undisciplined, self-indulgent, sophisticated, and liberal towards homosexual encounters. ${ }^{5}$ There is evidence of gay unions in both Ancient Rome and Greece. Emperor Nero married the freedman Pythagoras, as well as the young Sporus. Nero took on the role of bride during his marriage to Pythagoras, and the role of groom to Sporus, whom he had castrated and dressed in women's clothes to represent the bride. ${ }^{6}$ Such unions were modelled on the binary of male as active and female as passive pervasive in Roman civilisation; casual sexual encounters were modelled on the soldier as active and the slave as passive (rarely the other way around). ${ }^{7}$ The Ancient Greeks similarly embraced homosexuality, but did so often as a form of pederasty (male homosexuals penetrating adolescent males). ${ }^{8}$ Outside of

\footnotetext{
${ }^{3}$ Marilyn Irvin Holt, Mamie Doud Eisenhower: The General's First Lady (Lawrence: University Press of Kansas, 2007).

${ }^{4}$ Camille Paglia, Sexual Personae: Art and Decadence from Nefertiti to Emily Dickinson (London: Yale University Press, 1990).

${ }^{5}$ Ibid.

${ }^{6}$ Caroline Vout, Power and Eroticism in Imperial Rome (Cambridge: Cambridge University Press, 2007), p.151.

${ }^{7}$ Ibid.

${ }^{8}$ Andrew Lear and Eva Cantarella, Images of Ancient Greek Pederasty: Boys Were Their Gods (London: Routledge, 2008).
} 
sexuality, the Greeks were thought of as decadent by worshipping what Nietzsche called 'the whole Olympus of appearance', where the forms of visual arts or words were taken as a very serious matter; they 'were superficial-out of profundity'. 'The connection between the Greeks' emphasis on form and decadence is what Kearns describes as 'the moral force of beautiful forms', a philosophy ascribed to by the French Parnassian Théophile Gautier. ${ }^{10}$ The 'art for art's sake ${ }^{11}$ movement of the late 19th century, which models itself significantly on Gautier's sense of ironic detachment, is present in the work of Swinburne, Baudelaire, Pater, Poe, Huysmans, and in the witty writings of Wilde in The Mauve Decade of the late Victorian period. It offered a way of seeing life as an imitation of art, emphasising a strong bond between beauty and form, and a style of decadence that detached nature and sex from moral and social influences.

Art allows us to confront our own moral judgements by emphasising sexual interest as a natural phenomenon. Pornography is one such art form, as Sontag argues in 'The Pornographic Imagination', that provocatively encourages viewers to confront their morals in that it knowingly crosses certain boundaries and invites responses that recognise the primitive, the animalistic, and the natural. ${ }^{12}$ This is true of both soft and hardcore pornography, or even art which tends towards the erotic. Luis Buñuel's L'Age d'Or (1930), which contains erotica, encourages the viewer to make moral judgements by positioning morality as a conflicting point of interest within the content of the film itself. Towards the end of the film, we see a figure resembling Jesus, and a number of dukes, emerge innocently from the Château de Selliny. They proceed to walk across the drawbridge. From the images alone, we have no reason to believe that there is anything untoward afoot. But through Buñuel's juxtaposition of these images with the words '120 Days of Depraved Acts' (alluding to Sade's Les 120 Journées de Sodome), it is implied that the dukes have been engaged in orgies. The irony of this sequence is that those figures who preach about never committing a sin of the flesh are often guilty of just that. In many of the film's other sequences, Buñuel makes a mockery of moral codes (as per the Surrealist tradition) by emphasising instinctive behaviour and natural sexual urges. ${ }^{13}$ What is implied by Buñuel in this film as a whole is that attempts

\footnotetext{
${ }^{9}$ Friedrich Nietzsche, The Gay Science [Die fröhliche Wissenschaft], trans. By Josefine Nauckoff (Cambridge: Cambridge University Press, 2001), p.8.

10 James Kearns, Théophile Gautier, Orator to the Artists: Art Journalism in the Second Republic (London: Modern Humanities Research Association and Maney Publishing, 2007), p.68.

${ }^{11}$ Ibid.

12 Susan Sontag, Styles of Radical Will (London: Penguin Books, 2009), pp.35-73.

${ }^{13}$ Mocking moral codes, emphasising instinctual behaviour, and prioritising automatism over conscious, free will, can be found more broadly in the Surrealist circle of artists, poets, and filmmakers during the 1920s and 1930s in France and Spain. As outlined in Breton's Manifeste du Surréalisme, those operating in this circle were influenced by Freudian notions of the unconscious mind, and the overarching principles of pleasure and
} 
to suppress or restrain this behaviour to extremes is a vain enterprise; decadence, subversion, and a turn towards nature are seen as an unavoidable part of the human condition.

However, challenging a moral order need not only be done through mockery. For instance, Jack Smith's Flaming Creatures (1963), a film defended in a testimony by Sontag in 1964 after it was considered in breach of obscenity laws due to its depiction of intersexuality and transvestism, is about the innocence of Eros in all its forms and is not mockingly subversive. ${ }^{14}$ Pink Narcissus knowingly challenges moral codes present during its production, but it also takes us into a world which goes beyond sexuality, delving into the fundamental practices of sex itself. That is to say, there is a return to nature. Rousseau and Wordsworth had this mindset, but they believed in nature's benevolence and man's inherent virtuousness. Primitive life to them was untroubled; a return to nature would free humanity from burden. However, Bidgood observes that this turn to nature has consequences. Under the sweet, serene surface of natural beauty is a dark undercurrent and a world of violence, chaos, and sadism, as envisaged in the literary works of the Marquis de Sade. Through an appraisal of Pan's role-playing fantasies and his fictitious return to nature, I posit that there exists a romanticised, sentimental view of sex, which is its oneness with the beauty of nature, and its existence as separate from moral codes and social expectations. But in considering the juxtaposition of these sequences with the harsh realities of the city underground, I shall argue that Bidgood sees both the beauty and danger of homosexual encounters in such scenarios, and recognises that whilst homosexuality itself is not decadent, the practices seen in this film are presented in such a visceral way that they would ipso facto be defined as decadent for their dismissal of moral and social conventions.

The world of decadence and sexual liberation that Bidgood portrays addresses a paradox about freedom. He delves into the dominant-submissive fantasies that emerge out of a disdain for the idea that we are completely free. If we are completely free, then what is there left to subvert? Pan fantasises briefly about being a Roman emperor and then a slave to one. This very idea is executed in the cross-cutting between Pan's apartment and the fantasy world of Ancient Rome he has constructed in his mind, although the whole set-up with the waiter is also a fantasy. At the start of the scene, we see Pan lying gracefully on his bed, from which he calls a waiter to his door. When the waiter arrives, Pan opens the door and invites

reality. More specifically, they tap into the drive for sustenance ('Eros') and the human reality of facing death ('Thanatos'). Examples of such works include Buñuel and Dali's Un Chien Andalou, Dali's La persistencia de la memoria, Dulac's La Coquille et le clergyman, and Man Ray's Les Mystères du Château de Dé.

${ }^{14}$ John Leland, "The Prosecution Resets In A 1964 Obscenity Case", Nytimes.Com, 2015

$<$ https://www.nytimes.com/2015/11/01/nyregion/the-prosecution-resets-in-a-1964-obscenity-case.html> [Accessed 30 January 2019]. 
him in to place the champagne soaked in a bucket of ice on the table. But before we see him walk over to the table, a juxtaposition occurs: Pan's soft pink room transforms into the interior of an emperor's palace. The slow tempo of a soothing harpsicord is replaced by a sequence of minor chords on the piano. The sound becomes dissonant and disconcerting, evoking an air of melancholy and solemnity, and reflecting the downbeat mood of the laboriously working slave roleplayed by the waiter in Pan's fantasy. The slave/waiter walks through the atrium with a huge plate of grapes (replacing the champagne) to the room where the emperor (imitated by Pan) sits atop his solium. The slave then kneels in deference, offering him the fruits. The film cuts back to Pan's bedroom, where in a two-shot, we see Pan sitting on this bed in the foreground, side-on from the camera, and the waiter placing the champagne down on the table in the background. While Pan does not make eye-contact with the waiterhe looks directly ahead, while the waiter is situated to his right (but to us, the waiter is farthest away in the composition) — the waiter does turn to look at him. In this moment, Bidgood implies that they possibly share each other's fantasises, but are putting on a veil of false decorum to imitate a moral code. Bidgood then cuts back to the Roman palace, where we see Pan seated in a very genteel, unimposing fashion. He has golden locks, a glistening tan, and a very youthful face; here, Bidgood is invoking a Julius Caesar or Mark Antony figure in a tongue-in-cheek fashion. Here, power is not charged with militancy or brutality, but with elegance and sophistication. Thus, Pan's fantasy is a process of acting out of false power where the dominant wilfully seduces the submissive, and the submissive wilfully gives in to the dominant.

The source of power is simultaneously a source of decadence; androgynous men touching and kissing each other sensitively, bathed in a gentle, purple light, adapt themselves effortlessly to an environment that is confident in its power, so much so that pleasure and sex are seen as a matter of routine in the orders of the court. When the emperor summons two heavily-armed and masculine soldiers to bring in a prisoner slave, we find that Pan is now imitating this role too. Despite this aura of discipline, the fantasy Pan has constructed here is one where he knows all too well the decadent lifestyles of the Romans. A composite shot of emperor and slave seen in close proximity bursts with homoeroticism. Beneath the veneer of discipline is the sexual dynamic of giver and receiver. The slave evidently takes as much pleasure being passive as the emperor does in being dominant. Whilst we only see their two faces in this shot, beforehand, they are both shown to be naked, so when the slave slowly closes his eyes and tilts his head back, it evokes sensuality. Given that homosexuality was illegal during most of this film's production, this whole fantasy based on the spirit of a Roman 
world where homosexuality could practiced without shame, and the creation of false hierarchies, boundaries and a new or reinvented moral code, intensifies both the eroticism and decadence of the film. These false hierarchies appear symbolically in allusions to bondage, domination, and sadomasochism. A biker, dressed in leather, revs his bike and is cajoled into riding it towards Pan, who summons him as a matador would a bull. It subtly conveys the thrill of taking risks in the sexual underworld and the willingness to place oneself in danger for pleasure. Cross-cutting between the bike riding towards Pan, and Pan himself, playfully suggests penetration. It is not romantic; the adrenaline of the shot is portrayed as physically driven and lustful.

In presenting the homosexual underworld as lustful and dangerous, Bidgood gives an insight into the culture of meeting strangers for sex and the a priori knowledge that these men have of its unpredictable and risky nature. This includes the danger of being caught by onlookers in a time when homosexual sex was illegal. Bidgood's presentation of such images epitomise the precarious world of the 1960s homosexual underground, even in a time before the AIDS epidemic in the 1980s. I shall come to this bleak, even disturbing, depiction by Bidgood of this suburban world in the final section of this paper, but firstly one should consider the conflict brought to the fore by Bidgood's embrace of nature. On the one hand, there is the recognition that the world is not inherently safe and that human beings do have the potential to be primitive, animalistic, and dangerous in the face of others. On the other hand, there is the recognition of nature as a force that creates beautiful things, particularly its shaping of the human form, and more specifically to Bidgood, the male body. In viewing nature through both these prisms, Bidgood suggests that the perception of homosexual acts as socially and morally transgressive is simplistic and reductive, especially when considering nature as an all-encompassing power whose effect can be at once delightful and menacing, especially in the realm of sex.

What we get from Bidgood in the following sequence is a romanticised, idealistic, and possibly naïve view of the homosexuality by showing its oneness with nature as something benevolent and inherently agreeable. Bidgood knows this not to be true given what we see before this, but what this does is just add to the irony of clichéd representations. Mussorgsky's score, Night on Bald Mountain, reaches its final section in the transition between an abstract representation of a sex scene near a urinal and Pan's apartment; the music becomes serene, tranquil, and fluty, at one with the untroubled, untainted world of his bedroom. This scene emphasises Pan's direct experience of the body and the fantasies which are a most pleasurable thought when seen in relation to nature itself. At the start of the scene, Pan takes off his 
clothes in a sensual manner, as if he is seducing the man who appears before him in a dreamy haze. When he removes the clothes, he closes his eyes and fantasises about the pleasurable experience of being softly caressed. A spell of momentary pleasure is implied by a cut to a shot of him lying down and turning his head towards the camera, in ecstasy, in a wild landscape, before it cuts back to his bedroom where he finds a track to play on his record player with a gramophone speaker. The song he chooses is Kay Kyser and his Orchestra's '(I've Grown So Lonesome) Thinking of You', with Harry Babbit's vocals, from the 1930s.

From the moment Mussorgsky's Night on Bald Mountain fades out, and we hear the initial crackles of the needle touching the moving record, we are presented with a character who is clearly lost in the moment. Nothing matters to him more than a contemplation of his own sensuality and beauty. Hearing the lyrics of the song whilst Pan strolls around is in one sense a form of ironic detachment, in that his habit of indulging narcissistically in his own thoughts seems at odds with a stream of consciousness where he would say such a thing as 'I've grown so lonesome, thinking of you'. But, in another sense, we could argue that beyond the façade of his own narcissism, there is an inner desire to think about those he most fantasises about. He has 'grown lonesome' by virtue of the fact that his proclivities are much more difficult to fulfil in a society forbidding such acts. We are drawn to his own concerns with his beauty, and it appears the client he summons on the phone is nobody, only the fantasy of summoning an image of himself in an external bodily form, and born out of his conception of his own beauty. When he dials the number on his flamboyantly ornamented phone for instance, Bidgood gives us a still, big close-up shot of Pan revealing a homoerotic, even androgynous depiction of his face. The cool, Hollywood-style image of him smoking his cigarette has a masculine edge to it, but the longevity of the take, the softness of the image, the mix of blue and pink light, the youthful, smooth facial features, and the elongated blink showing off his physique, point to the iconic image of the beautiful young man. This shot contemplates the figure of the young man, fixating on his form as the camera is trying to immortalise a beauty that the viewer knows to be transient.

Such a longing for beauty as something distinct from time can be found in Shakespeare's sonnets, and in one of his earliest poems, Venus and Adonis, which was influenced by Spenser's The Faerie Queene, another epic tale of a youthful man. Similarly, in Wilde's The Picture of Dorian Gray, Basil Hallward and Lord Henry are in absolute awe of the figure of Dorian Gray depicted in Hallward's painting. Wilde describes him as the "young Adonis [...] who looks as if he was made out of ivory and rose-leaves". ${ }^{15}$ When Pan lies on

\footnotetext{
${ }^{15}$ Oscar Wilde, The Picture of Dorian Gray And Other Writings, (London: Pocket Books, 2005), p.7.
} 
the bed and undoes his trousers, he looks into the mirror and finds only himself looking back at him, what he is looking at through the mirror is the reflection of a figure completely immersed in a rustic setting. He is at one with nature - nature is the benevolent force whose power to strip things of their beauty over time is repressed to preserve the myth of eternal beauty. The elevation of beauty above all else speaks to the idea of the expressive and artistic as detached entities from the moral and social restrictions in life; the depth of his appreciation for the senses and for the forms which outline his own beautiful existence distances the moral and social realms and positions him at one with nature, and nature alone.

The contrasts Bidgood makes between the benevolent and dark forces of nature imitate his own experiences from the underground. The domination fantasy outlined above is taken to the extremes in a later scene set on the city streets, extending beyond fantasy to the dangers of reality. The city is a transient space with a hive of activity amongst the dwellers; therefore, some of the intricacies of city life go unnoticed. Bidgood injects into his depiction of city life a feeling of the peculiar and bizarre. We almost get the sense that he is conveying such life as theatre, or more specifically, as carnival performances or side show acts. Erving Goffman describes life as a metaphor for theatre; the series of spontaneous performances are given coherence through Bidgood's dramaturgy of shared aberration. ${ }^{16}$ Everything to the audience appears loud, strange, and chaotic, but Bidgood suggests that all of the people in this space are like actors performing on a stage. It is as if each person has been in a rehearsal, knowing how others around them act and behave. The paradox here, and one that Bidgood arguably wanted his homosexual audience to notice, is that an aberration in the city is the norm to those who have been underground. The 'BURLESK' sign seen earlier in the film from Pan's window, the various stalls compartmentalising individual acts, and the radiophonic voice-over offering commentary on what life is like in the city, all allude to the decadence in the city, simultaneously making it matter of fact. A man standing in the telephone box, appearing at first to be merely part of the urban décor, perhaps making an innocent call, is in fact telephoning Pan. Before we were taken to the city, Bidgood showed Pan looking intently at his telephone as if expecting a client to phone through very soon.

A subtle hint is dropped in two juxtaposing visuals, showing Pan preparing for penetration by an unknown man. The first is a shot of the mysterious man on the phone in a glass booth, standing silently and waiting patiently for a response. Behind him is the illuminated nightscape of the city. The lights on the building light up half his face and leaves the other half in shadow. This is an archetypally villainous shot. The viewer is led to question,

${ }^{16}$ Erving Goffman, The Presentation of Self in Everyday Life (New York: Anchor Books, 2008). 
who is this man and what does he want from Pan? Does he just want sex, or could he be a less-than-innocent figure who could potentially put Pan in danger? The long shadow that runs across the caller's face, the rain tapping against the glass, and the look of seriousness on his face, adds to the menacing, antagonistic feel of the character. When this shot is cross cut with a long-shot of Pan spread across the bed in his sweet, pink apartment in the prone position, with the back of his legs and buttocks facing us, it is implied that Pan is waiting for a sexual encounter. The mysterious older man, whose sexuality is not obvious even if his desires are, typifies what in the gay community is often termed 'trade', a possible, non-identified gay who wants sexual fulfilment. On the other hand, he could be an older gay man who is willing to reward Pan financially in exchange for sex. What Bidgood reveals in these visuals in this case is the thrilling, dangerous, and discreet nature of casual sex. All of these emerge from a fear of one's sexuality being exposed in a place where such an act is illegal, as well as the uncertainty around the individual one chooses to converse with on the phone and meet in person.

City life in the underground is shown to be a continuous cycle of unpredictability and unrestraint. When the man in the booth is on the phone, he looks across at one point and Bidgood takes this cue to cut to a homeless man searching for food in a bin. Reflected on the glass of the booth for a brief moment also is the text from a lit sign reading 'WE ARE ALWAYS OPEN'. The city never sleeps, and neither do the sexual desires nor erotic fantasies of people who inhabit these spaces. Bataille, in L'Erotisme, responded to Sade's claim that 'there is not a libertine some little way gone in vice who does not know what a hold murder has on the senses', with his definition of eroticism as 'assenting to life up to the point of death'. ${ }^{17}$ Bataille recognised the paradox in Sade's statement, revealing that 'the sight or thought of murder can give rise to a desire for sexual enjoyment', and that recognising this gruesome fact is necessary in contemplating human existence. ${ }^{18}$ This is true of the moment Pan leaves his safe environment and walks out into the dark shadows of the city to fulfil his quest for pleasure. On his quest, we hear innuendos of various kinds from a commentator who comments on what is going on in the scene as if they were performances at a freak show. Bidgood is often very suggestive, as in the following humorous and hyperbolic allusion to oral sex spoken as we see the contrastingly intense cut from Pan lying in the prone position to a frontal shot of the mysterious man (accompanied by the descending, minor scale music):

\footnotetext{
${ }_{17}$ Georges Bataille, Erotism: Death and Sensuality [L'Erotisme], trans. by Mary Dalwood (San Francisco: City Lights Books, 1986), pp. 11-12.

18 Ibid., pp. 11-12.
} 
“'The chief is going to eat twenty-eight inches [...] I know a great many of you people who don't think that's possible, so I am going to have to show you that over here on platform three". ${ }^{19}$ Bidgood here, and in the many other instances we hear the radiophonic voice, points to a broader trend in the sexual underground: performing sexual acts in the street for pleasure, but often in the shadows of the city so as to minimise the risk of being seen. When Pan heads out on to the streets, and when he uses the urinals, he is stared at and admired in a disturbing manner by the aforementioned client. The client even looks over his shoulder as he urinates. Pan sheds his camp-ness and adopts the masculine image by smoking a cigarette in front of him; he is aware of danger, but acts with decorum to maintain his strength and to give his client what he wants. Bidgood is demonstrating here that the sexual underworld is far from pristine; it is a place full of desire and pleasure, but at the same time there is an underlying sense that searching for these desires and pleasures may have consequences.

The world of Pink Narcissus brings together all the elements of the frequently represented aspects of the homosexual male lifestyle, including the extreme antitheses. Bidgood weaves all these strands together in a denouement rich with symbolism and attentive to beauty. The power, which Pan, as a narcissist, sees in nature, is often one that regulates beauty and form. But by the end of the film, when he fully exposes himself to the elements and stands in the pouring rain whilst thunder and lightning rages around him, he also sees it as the true limit. Whilst he is able to detach himself from morality by dreaming about himself as being unified with nature, he recognises that he cannot transcend the power of nature, or indefinitely preserve his beauty. At one point, he stretches his arms outwards, and looks up at the sky as if emulating Jesus or Saint Sebastian, martyrs punished because they were thought to be traitors. Bidgood does not surrender Pan to morality. Pan reinforces the sheer superficiality of morality in the face of nature, but underscores how the homosexual act is often defined as a moral rather than natural act, thus a decadence. With this, Bidgood also suggests that morality is far inferior to the power of nature. In a series of very low-angle shots, Pan walks through the wilderness, but due to the camera position, he towers above like a giant or a godlike figure. Mussorgsky is heard again at this moment—a leitmotif throughout this film which reflects the whole spectrum of the homosexual world, from serenity and beauty, to danger and lust—which in combination with the visuals, brings this film full circle. When Pan undresses at the end of the film, and a client enters in a bowler hat, we learn that this client is also Pan. The Pan in the bowler hat then looks at himself and breaks his sacred

\footnotetext{
${ }_{19}$ Pink Narcissus, James Bidgood. La Folie des Hommes, Pink Pictures Ltd, 1971. The above transcription is mine. This utterance can be heard at 40 minutes, 43 seconds to 40 minutes, 53 seconds.
} 
mirror in displeasure of the sexual experiences he encountered in the city. The cracks of the mirror, through a match cut, transform into the ugliness of a spider's web. Bidgood brings our attention to a moral point here, which is that the closer one is to nature, the more decadent a person is. He is unable to resist temptation. Like the religious imagery mentioned above, Bidgood reinforces the primacy of nature by making a provocative gesture towards morality. He immortalises Pan's fleeting desires through homoerotic images that are rooted in the image of nature. Bidgood's film recognises that beauty is transient, and that decadence is something that can take a harsher form if nature intends, but ultimately, that nature is the homosexual man's salvation from a complex moral and social system. 


\section{Works Cited}

\section{Bibliography}

Bataille, Georges, Erotism: Death and Sensuality [L'Erotisme], trans. By Mary Dalwood (San Francisco: City Lights Books, 1986)

Edgecomb, Sean, "Camping Out With James Bidgood: The Auteur Of Pink Narcissus Tells All - Bright Lights Film Journal", Bright Lights Film Journal, 2019

$<$ https://brightlightsfilm.com/wp-content/cache/all/camping-james-bidgood-auteur-pinknarcissus-tells/\#.XFIYufZ2vmI> [Accessed 30 January 2019]

Goffman, Erving, The Presentation Of Self In Everyday Life (New York: Anchor Books, 2008)

Holt, Marilyn Irvin, Mamie Doud Eisenhower: The General's First Lady (Lawrence: University Press of Kansas, 2007)

Kearns, James, Théophile Gautier, Orator to the Artists: Art Journalism in the Second Republic (London: Modern Humanities Research Association and Maney Publishing, 2007)

Lear, Andrew and Eva Cantarella, Images of Ancient Greek Pederasty: Boys Were Their Gods (London: Routledge, 2008)

Leland, John, "The Prosecution Resets In A 1964 Obscenity Case", Nytimes.Com, 2015 <https://www.nytimes.com/2015/11/01/nyregion/the-prosecution-resets-in-a-1964obscenity-case.html> [Accessed 30 January 2019]

Nietzsche, Friedrich, The Gay Science [Die fröbliche Wissenschaft], trans. By Josefine Nauckoff, (Cambridge: Cambridge University Press, 2001)

Paglia, Camille, Sexual Personae: Art and Decadence from Nefertiti to Emily Dickinson (London: Yale University Press, 1990)

Sontag, Susan, Against Interpretation and Other Essays (London: Penguin Books, 2009) , Styles of Radical Will (London: Penguin Books, 2009)

Vout, Caroline, Power and Eroticism in Imperial Rome (Cambridge: Cambridge University Press, 2007)

Wilde, Oscar, The Picture Of Dorian Gray And Other Writings (London: Pocket Books, 2005)

\section{Filmography}

Boys in the Sand, Wakefield Poole. Poolemar, 1971

Flaming Creatures, Jack Smith. Jack Smith (self-funded and produced), 1963

L'Age d'Or, Luis Buñuel. Corinth Films, 1930

Pink Narcissus, James Bidgood. La Folie des Hommes, Pink Pictures Ltd, 1971 